\title{
Profile of The Indonesian Essential Oil from Melaleuca cajuputi
}

\author{
Sutrisno* and Rini Retnosari \\ Department of Chemistry \\ Universitas Negeri Malang \\ Malang, Indonesia \\ sutrisno.kimia@um.ac.id
}

\author{
Henie Poerwandar Asmaningrum \\ Department of Educational Chemistry \\ Universitas Musamus Merauke \\ Merauke, Indonesia
}

\begin{abstract}
The chemical composition of three cajuput essential oils of Melaleuca cajuputi (M. cajuputi) from different area in Indonesia were analyzed using gas chromatography-mass spectrometry to determine the similarities and differences among their volatile chemical compositions. These cajuput oils come from Malang (East Java), Buru Island (Maluku), and Merauke (Papua). It contains 30 components of which 26 components have been identified. Cajuput oils in this research contained significant quantities of 1,8 -cineole (42-60\%), a-terpineole (4-18\%), caryophyllene (0.6$11 \%)$, and $\alpha$-pinene (3-12\%). Oil from Malang (East Java) also contained significant amounts of $\alpha$-selinene $(6.73 \%)$ and accompanied by lesser amounts of sesquiterpene detected only in this oil: valencene, germacrene B, ledol, globulol, epiglobulol, and viridiflorol. The hemiterpene compound, 2,4pentanediol (11.44\%), was only found in oil from Buru Island. Oil originating from Papua also contained $\alpha$-gurjunene $(17.31 \%)$ as the major component. Cajuput oil from Malang (East Java) has the highest number of chemical components than the others.
\end{abstract}

Keywords - cajuput oil, Indonesian essential oil, terpenoid

\section{INTRODUCTION}

Cajuputi or kayu putih (Indonesian name) known as Melaleuca cajuputi (M. cajuputi) is used as source of cajuput oil commercially in industry. There are many kinds of cajuput oil product in Indonesian market. Generally, people use this oil as household medication to relieve flatulence, nausea, colds, and itchy. M. cajuputi spread almost throughout the territory of Indonesia. Based on its natural distribution there are three subspecies of $M$. cajuputi in Indonesia. M. cajuputi subsp. cajuputi Powell grows in the east Indonesia (Maluku Island), M. cajuputi subsp. cumingiana Barlow grows in the west Indonesia (Sumatera, West Barat, and South Kalimantan), and M. cajuputi subsp. platyphylla Barlow grows in South Irian Jaya, Aru Island, and Tanimbar Island [1]. M. cajuputi growing in wide variation of geographical range caused genetic variation among them. It can be shown in their morphology and essential oil characteristic.

The main components of essential oil obtained from M. cajuputi subsp. Cajuputi were 1,8-cineole (15$60 \%$ ), sesquiterpene alcohol globulol (0.2-9\%), viridiflorol $(0.2-10 \%)$, and spathulenol (0.4-30\%). The essential oil of $M$. cajuputi subsp. cumingiana from Thailand and Vietnam contained $\gamma$-terpinene $(14-17 \%)$ and terpinolene (10-23\%) as the major components. But the oil from Kalimantan contained much larger amounts $\beta$-caryophyllene (23-44\%), humulene (9-14\%), and cajeputol (2-18\%).

There are two chemotypes of essential oil from cajuputi subsp. platyphylla. Chemotype I, reported from Bensbach River in Papua New Guinea, contained significant quantities of $\beta$-triketone (1acetyl-4-methoxy-3,5,5-trimethylcyclohex-3-en-2,5 -dione) (2-80\%) and cajeputol (3-57\%). Chemotype II contained $\alpha$-pinene $(12-70 \%), 1,8$-cineole $(0.1$ $10 \%), \gamma$-terpinen $(1-10 \%), p$-cymen $(0.1-7 \%)$, and $\beta$-caryophyllene (4-11\%) [3]. M. cajuputi subsp. cajuputi contains the largest amount of 1,8-cineole than the others. Commonly, subsp. Cajuputi is used as main source of commercial cajuput oil in the market.

Variation of geographical range contributes in wide range variation of secondary metabolites generated by plants. Cajuput oil from Cuba contained 38 compounds, including viridiflorol $(28.2 \%)$ and 1,8 cineole $(21.3 \%)$ as the major components [4]. Cajuput oil from South India contained significant amounts of (E)-Nerolidol (76.58-90.85\%), $\beta$ caryophyllene (1.52-4.49\%), viridiflorol (0.19$2.79 \%)$, $(E)-\beta$-farnesene $(\leq 0.10-2.67 \%)$, and $\alpha$ humulene $(0.22-1.03 \%)$ [5]. But, cajuput oil from North India contained 1,8-cineole $(19.9 \%), \beta$ eudesmol (15.8\%), $\alpha$-eudesmol (11.3\%), viridifloral $(8.9 \%)$, and Guaiol $(9.0 \%)$ as the major compounds [6]. It was the aim of this study to critically examine the similarities and differences among volatile chemical compositions of $M$. cajuputi from different area in Indonesian. Based on their natural distribution, M. cajuputi from Malang (East Java), Buru Island (Maluku), and Merauke (Papua) was chosen in this research and it represents the geographic range of Indonesian $M$. cajuputi. This study was used to propose biogenesis pathway of 
chemical components in the Indonesian cajuput oils.

\section{MATERIALS AND METHODS}

\section{A. Material}

Leave of $M$. cajuputi was collected from Malang (East Java), Buru Island (Maluku), and Merauke (Papua), Indonensia.

\section{B. Isolation of Essential Oils.}

The essential oils of $M$. cajuputi were obtained by steam distillation for $24 \mathrm{~h}$. Samples were steam distilled as soon as possible after their arrival from the field so that the leaves were still fresh. The obtained essential oils were then dried over anhydrous sodium sulphate to reduce water content.

\section{Physical Properties Analysis.}

The cajuput oils were then subjected to physical characterization. Color and state of the oils at room temperature were noted by visual inspection. The refractive index of the oils was determined using refractometer, while the specific gravity which was measured at room temperature was estimated by the use of a specific gravity bottle.

\section{GC-MS Analysis.}

Oil components were identified by gas chromatography - mass spectrometry (GC-MS) analysis. Shimadzu QP 2010S GC - MS was used in this research. The $\mathrm{GC}$ was equipped with a Carbowax column (30 m x $0.25 \mathrm{~mm})$. Helium was the carrier gas with total flow rate of $49.2 \mathrm{~mL} / \mathrm{min}$. The injection temperature was $240^{\circ} \mathrm{C}$ and the oven temperature program was as follows: $60^{\circ} \mathrm{C}$ initial temperature, hold for $5 \mathrm{~min}$, increased until $200^{\circ} \mathrm{C}$, and hold for $41 \mathrm{~min}$. Mass spectra were obtained at $70 \mathrm{eV}$. Peaks were confirmed by library searches and comparisons with authentic samples.

\section{RESULTS AND DISCUSSIONS}

\section{A. Physical Characterization.}

The physical properties of three cajuput oils from Indonesia are listed in Table 1 . The state at room temperature was generally liquid and the colors of the oils were green. The oils from Malang had the highest values of specific gravity and refractive index.

TABLE I. PHYSICAL PROPERTIES OF CAJUPUT OILS FROM MALANG, BURU ISLAND, AND MERAUKE

\begin{tabular}{|l|c|c|c|}
\hline \multirow{2}{*}{ Properties } & \multicolumn{3}{|c|}{ Cajuput Oils } \\
\cline { 2 - 4 } & Malang & Buru Island & $\begin{array}{l}\text { Merauk } \\
\boldsymbol{e}\end{array}$ \\
\hline Phase at ambient & Liquid & Liquid & Liquid \\
\hline Colour & Green & Green & Green \\
\hline $\begin{array}{l}\text { Specific gravity } \\
\left(\mathrm{g} / \mathrm{cm}^{3}\right)\end{array}$ & 0.894 & 0.888 & 0.887 \\
\hline $\begin{array}{l}\text { Refractive index } \\
\text { at ambient }\end{array}$ & 1.479 & 1.468 & 1.469 \\
\hline
\end{tabular}

\section{B. Chemical Compositions Distribution of Three Cajuput Oils from Indonesia.}

A total of 30 compounds were detected from three cajuput oils in this research but only 26 compounds have been identified. Table I shows chemical composition of each cajuput oils. Oil from Malang contained 20 compounds that have been identified. It was made up largely of oxygenated monoterpenoids $\quad(60.3 \%), \quad$ sesquiterpene hydrocarbons $(25.59 \%)$, and monoterpene hydrocarbons $(10.22 \%)$ with lesser amounts of oxygenated sesquiterpenoids (3.43\%) and phenylpropene $(0.46 \%)$. The most abundant essential oil components were 1,8-cineole (41.60 $\%), \alpha$ - terpineole $(18.19 \%)$, caryophyllene (10.60 $\%), \alpha$ - selinene $(6.73 \%)$, limonene $(4.8 \%)$, and $\alpha$ - pinene $(3.19 \%)$.

Oil from Buru Island contained 19 compounds but only 17 compounds have been identified. This oil contained significant amount of oxygenated monoterpenoids $(63.65 \%)$, monoterpene hydrocarbons $(20.07 \%)$, and oxygenated hemiterpenoid (11.44\%), with lesser amounts of sesquiterpene hydrocarbons (3.64\%) and phenylpropene $(0.54 \%)$. The major compounds of this oil were 1,8 -cineole $(50.64 \%), \alpha$-pinene $(12.17$ $\%), 2$,4-pentanediol (11.44\%), $\alpha$-terpineole (10.98 $\%)$, and limonene (3.61\%). Oil from Merauke contained the lowest number of compounds than the others. 14 compounds were detected from this oil but only 12 compounds have been identified. It was made up largely of oxygenated monoterpenoids $\quad(64.75 \%), \quad$ sesquiterpene hydrocarbons $(19.19 \%)$, and monoterpene hydrocarbons $(14.92 \%)$ with lesser amounts of oxygenated hemiterpenoid $(0.42 \%)$ and phenylpropene $(0.61 \%)$. The major compounds of this oil were 1,8 -cineole $(59.90 \%), \alpha$-pinene $(11.86 \%), \alpha$-gurjunene $(17.31 \%)$, and $\alpha$-terpineole (4.85\%). Oxygenated monoterpenoid was the most abundant component in all samples. Hemiterpene, as precursor of monoterpene and sesquiterpene, was only found in oil from Buru Island and Merauke.

Cajuput oil from Malang has the highest number of chemical components than the others. It's likely because this oil come from Java Island. This Island was industry area and densely populated so that environment stress from household waste, motor vehicle pollution, and industrial waste was high and plants produced a wide variety of secondary metabolites to survive. However, in Papua, environmental conditions were still not contaminated with industrial waste and motor vehicle pollution. The number of residents was still sparse and their area was grown by tropical forest that has never been touched by humans. So that, the number of chemical components of cajuput oil from Papua was the lowest than the others because the environment stress was low. 
TABLE II. CHEMICAL CONSTITUENT OF THREE CAJUPUT OILS FROM INDONESIA

\begin{tabular}{|c|c|c|c|c|}
\hline \multirow[b]{2}{*}{ No } & \multirow[b]{2}{*}{ Compound } & \multicolumn{3}{|c|}{$\%$ in Oil } \\
\hline & & Malang & $\begin{array}{c}\text { Buru } \\
\text { Island }\end{array}$ & $\begin{array}{c}\text { Merauk } \\
e\end{array}$ \\
\hline 1 & $\begin{array}{l}\text { 3-Methyl } \\
\text { butanal }\end{array}$ & - & - & 0.42 \\
\hline 2 & $\alpha$-Pinene & 3.19 & 12.17 & 11.86 \\
\hline 3 & $\beta$-Pinene & 1.94 & 1.08 & 1.11 \\
\hline 4 & 3-Carane & - & 0.93 & - \\
\hline 5 & $\beta$-Myrcen & 0.51 & 0.28 & 0.41 \\
\hline 6 & Limonene & 4.28 & 3.61 & 1.31 \\
\hline 7 & 1,8-Cineole & 41.60 & 50.64 & 59.90 \\
\hline 8 & $\gamma$-Terpinene & - & 0.79 & 0.23 \\
\hline 9 & $p$-Cymen & 0.3 & 0.71 & - \\
\hline 10 & Terpinolene & - & 0.50 & - \\
\hline 11 & Linalool & 0.51 & 0.21 & - \\
\hline 12 & Caryophyllene & 10.60 & 1.6 & 0.66 \\
\hline 13 & $\alpha$-Gurjunene & 0.50 & - & 17.31 \\
\hline 14 & 4-Terpineol & - & 1.82 & - \\
\hline 15 & 2,4-Pentanediol & - & 11.44 & - \\
\hline 16 & $\alpha$-Humulene & 5.51 & 1.09 & 1.22 \\
\hline 17 & $\alpha$-Terpineol & 18.19 & 10.98 & 4.85 \\
\hline 18 & Cadinen & 0.68 & - & - \\
\hline 19 & $\alpha$-Selinene & 6.73 & 0.95 & - \\
\hline 20 & Valensene & 1.22 & - & - \\
\hline 21 & Germacrane B & 0.35 & - & - \\
\hline 22 & Ledol & 0.20 & - & - \\
\hline 23 & Globulol & 0.76 & - & - \\
\hline 24 & Epiglobulol & 1.90 & - & - \\
\hline 25 & Viridiflorol & 0.57 & - & - \\
\hline 26 & Eugenol & 0.46 & 0.54 & 0.61 \\
\hline
\end{tabular}

The major components of all samples were 1,8cineole $(42-60 \%)$, $\alpha$-terpineole $(4-18 \%)$, caryophyllene $(0.6-11 \%)$, $\alpha$-pinene $(3-12 \%)$, and limonene $(0-5 \%)$. Oil from Malang also contained significant amounts of $\alpha$-selinene (6.73 $\%)$, oil form Buru Island contained hemiterpene compound, 2,4-pentanediol (11.44\%), and oil from Merauke also contained $\alpha$-gurjunene (17.31\%) as the major component. It can be concluded that the content and variation of the major components was different among all samples, so that geographical and environmental condition influence the wide variety of secondary metabolites produced by plants. The major components of cajuput oil from Palembang (Sumatera) were 1,8-cineole (31.78\%), caryophyllene homolog $(6.55 \%)$, cadinene homolog (11.88\%), and (-) - Globulol (10.38\%). However, cajuput oil from Yogyakarta (Java Island) contained significant amount of 1,8-cineole $(55.16 \%)$, caryophyllene homolog $(9.09 \%)$, and caryophyllene $(4.64 \%)$ [7]. The major components of Vietnamese cajuput oil were 1,8-cineole $(41.1 \%), \gamma$-terpinene $(4.6 \%)$, limonene $(4.1 \%), p-$ cymen $(6.8 \%)$, and terpinolene $(5.9 \%)$ [8].

All samples contain one major component, 1,8cineole, which is reported as being a common major contributor to M. cajuputi subsp Cajututi. However, according to [1], commonly M. cajuputi subsp. cumingiana Barlow grows in West Indonesia and M. cajuputi subsp. platyphylla Barlow grows in Irian Jaya, but all samples was subsp. cajuputi.
Gunn dkk, 1996 (in cited [2]) stated that grading of cajuput oil depends on its location of harvest in the Maluku Island. The abundance of 1,8-cineole in the oil which appears to be associated with the locality of harvest in the Maluku Islands. Grade 1, the best quality oil, has an average cineole content of $62 \%$ in the Maluku Islands. But, Grade II has cineole content of $50.7 \%$ in the Java Island. The quality of cajuput oil depends on cineole content. Oil from Merauke has the most cineol content (59.9\%) among all samples, and as the best quality of cajuput oil is this research.

Chemical components in cajuput oil that have antimicrobial activity was 1,8-cineole, (-) Linalool, (-) - 4-Terpineole, and $( \pm)-\alpha$-terpineole [9]. It is confirmed that 1,8 -cineole was the main active component responsible for its antibacterial and antifungal properties [10], [11], [12], [13], [14]. It has strong antibacterial activity against Bacillus cereus, Cryptococcus neoformans, Moraxella catarrhalis, Klebsiella pneumoniae, Pseudomonas aeruginosa, Escherichia coli, Staphylococcuc aureus, $S$. epidermidis, E. cloacea, C. albicans, $C$. vaginalis, and T. glabarata [10], [11]. 1,8-cineole also showed bactericidal activity with MIC of $0.375 \%$ against Listeria monocytogenes [15].

The oil from Melaleuca alternifolia Cheel., the other species of Melaleuca showed antimicrobial activity and anti-tumoral activity because of 4terpineol [16], [17], [18]. In this study, only oil from Buru Island contained this compound. It indicated that the antimicrobial activity of this oil is highest than the others and this oil has potency as anti-tumor. Beside that, Melaleuca alternifolia oil showed antioxidant activity because of $\alpha$-terpinene, $\alpha$-terpinolene, and $\gamma$-terpinene [19]. Therefore oil from Buru Island has potency as antioxidant.

\section{Biogenesis Pathway of Monoterpene and Sesquiterpene from Indonesian M. cajuputi.}

There are nine components that commonly detected among all samples but the content of each was different, including $\alpha$-pinene, $\beta$-pinene, $\beta$ myrcen, limonene, 1,8-cineole, caryophyllene, $\alpha$ humulene, $\alpha$-terpineole, and eugenol. Oil from Malang contains a wide variation of sesquiterpene type but oil from Buru Island and Merauke contains a wide variation of monoterpene type. Monoterpenes detected in all samples are linear and cyclic. Two linear monoterpenes $(\beta$-myrcene and linalool) is similar to linalyl dhiposphate (LPP). The biogenesis pathway of these compounds is proposed by ionization to the allylic cation of geranyl dhiposphate (GPP) which can thus allow a change in attachment of the diphosphate group (to the tertiary carbon in LPP) [20]. Linalyl cation loses a proton to give $\beta$-myrcene, but quenching of the linalyl cation with water can produce linalool. All cyclic monoterpenes were derived from $\alpha$ terpinyl cation formed by cyclization of LPP. 
Quenching of $\alpha$-terpinyl cation with water can produce $\alpha$ - terpineol, but losing a proton of $\alpha$ terpinyl cation produces limonene and terpinolene. Further cyclization of $\alpha-$ terpineol will be generated 1,8 - cineole. Bicyclic ring formation of $\alpha$-terpinyl cation will be generated $\alpha$-pinene and $\beta$ pinene. $\alpha$-pinene is more stable than $\beta$-pinene because it has upper end alkenes so that the content of $\alpha$-pinene found in this oil is higher than $\beta$ pinene. However formation of a cyclopropane ring will be produced 3-carene. Wagner - Meerwein rearrangements (1,2-hydride shift) of $\alpha$ - terpinyl cation produces 4 - terpinenyl cation allowing formation $\gamma$ - terpinene by losing a proton and $4-$ terpineol by quenching with water. Further dehydrogenation of 4 - terpinenyl cation will be generated $p-$ cymen. It can be concluded that $\alpha-$ terpinyl cation is precursors of cyclic monoterpenes detected in all samples. Commonly, all samples generate cyclic monoterpenes with menthane type, pinane type, and carane type. Biogenesis pathway of monoterpenes from Indonesian $M$. cajuputi can be shown in Figure 1.

There are 11 sesquiterpenes detected in all samples that are common in the form of cyclic. A-humulene and germacrane B are proposed as precursors of other sesquiterpenes detected in all samples. Formation of 10-membered ring as the result of farnesyl dhiposphate (FPP) cyclization will be generated germacrane B. However, formation of 11-membered ring as the result of FPP cyclization will be produced $\alpha$-humulene. Losing a proton of germacyrl cation formed from $E, E$-FPP, followed with cyclization to form two six-membered ring will be generated $\alpha$-Selinene. 1,2-methyl shift of $\alpha$ Selinene will be produced valencene. 1,3-hydride shift of germacyrl cation formed from E,Z-FPP, followed with followed with cyclization to form two six - membered ring will be generated cadinene. Extending the biogenesis of germacyrl cation will be generated $\alpha$-Selinene, valencene, cadinene. Other sesquiterpenes are resulted by extending the biogenesis of humulyl cation. Formation of a cyclobutane ring, as the result of cyclization $\alpha$-humulene will be generated caryophyllene. Further cyclization of $\alpha$-humulene formed cyclopropane, cyclopentane, and cycloheptane ring will be produced $\alpha$-gurjunene. Quenching of $\alpha$-gurjunene with water will produce ledol, globulol, epiglobulol, and viridiflorol. Commonly, all samples generate cyclic sesquiterpenes with humulene type, germacrane type, selinene type, cadinene type, caryophyllene and gurjunene type. Biogenesis pathway of sesquiterpenes from Indonesian $M$. cajuputi can be shown in Figure 2.

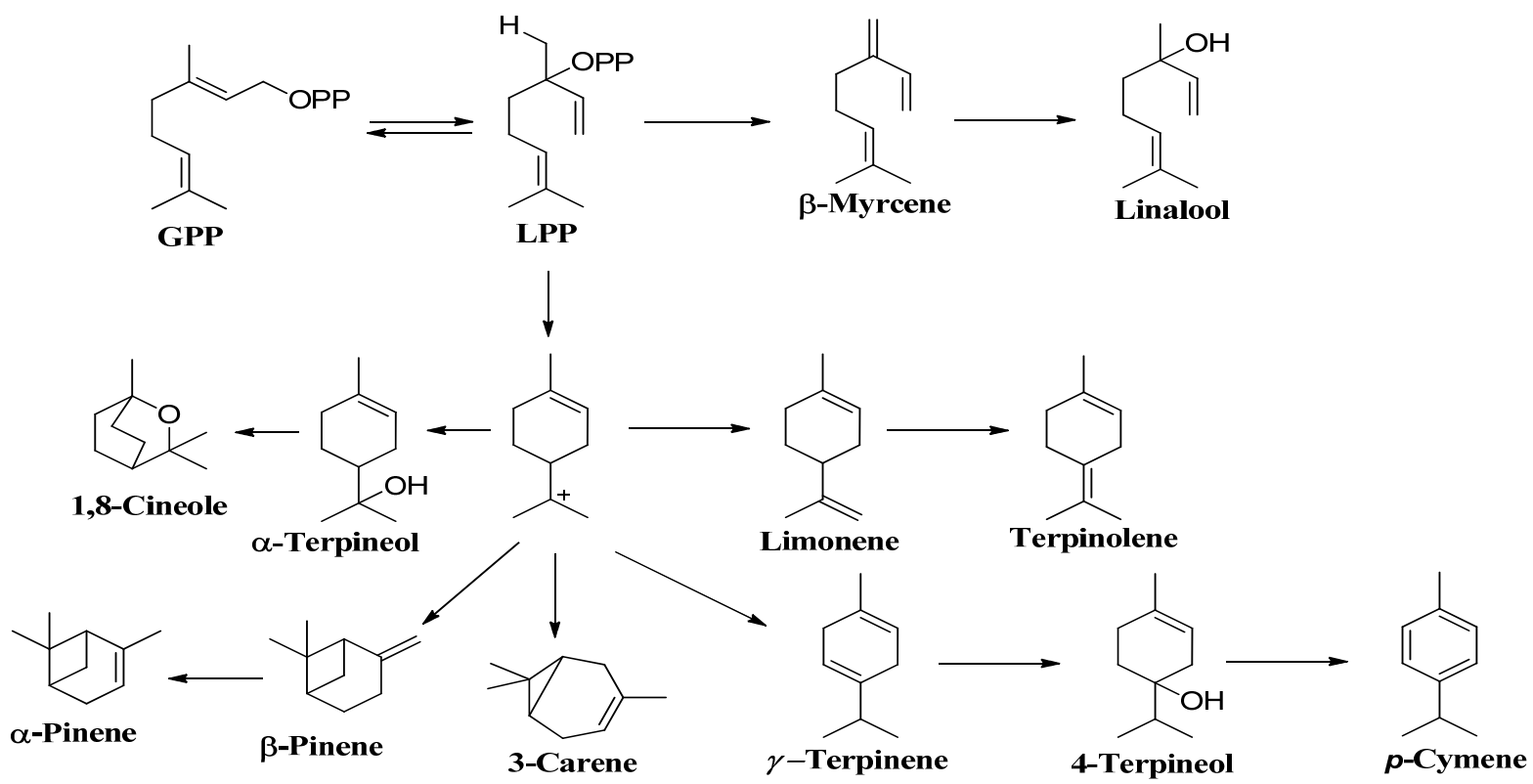

Fig.1 Biogenesis pathway of monoterpenes from Indonesian M. cajuputi 


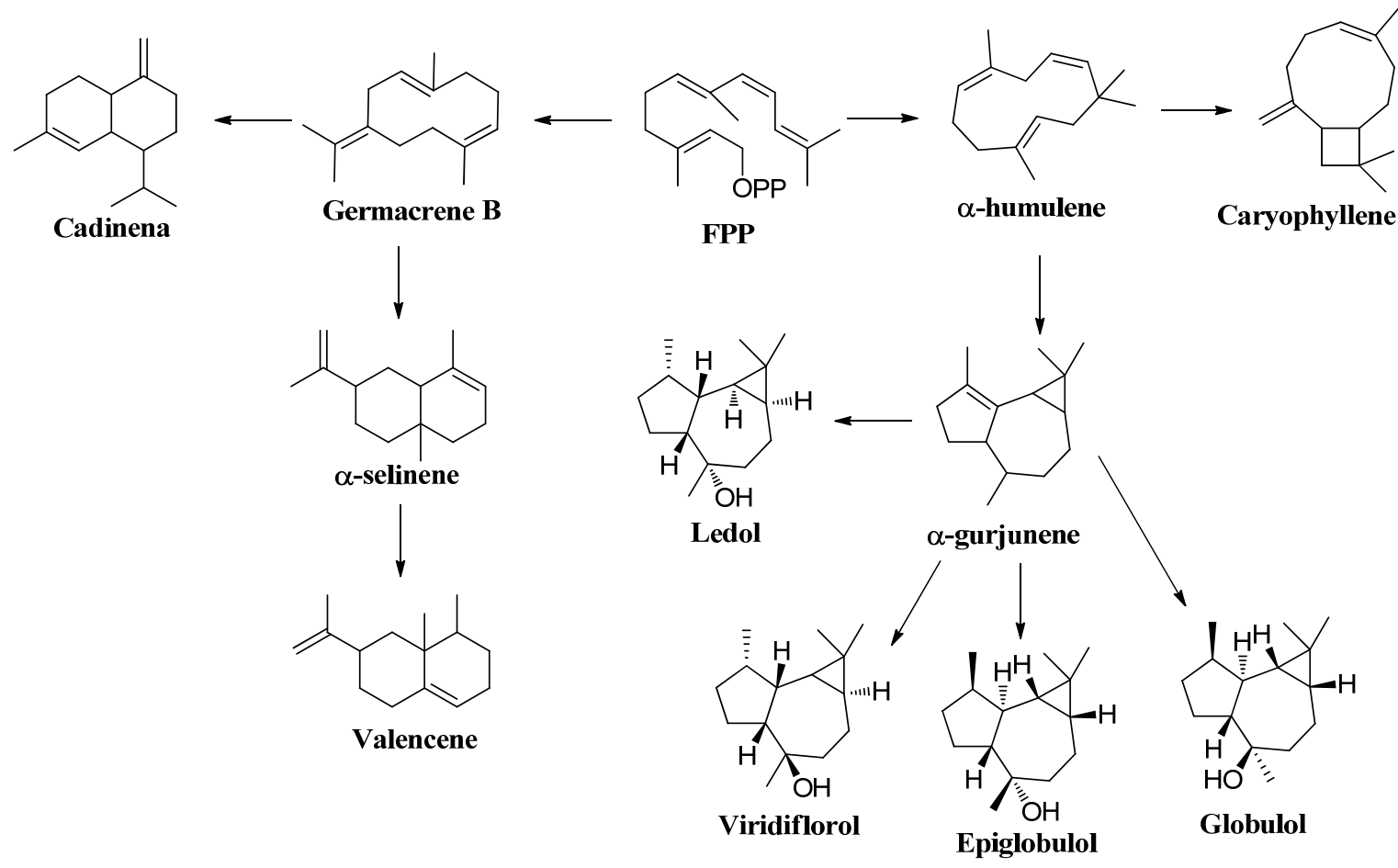

Fig. 2. Biogenesis pathway of sesquiterpenes from Indonesian M. cajuputi

\section{CONCLUSIONS}

A total of 30 compounds were detected from three cajuput oils in this research but only 26 compounds have been identified. The most abundant component of the cajuput oil was oxygenated monoterpenes. The common oxygenated monoterpenoids were 1,8-cineole, linalool, $\alpha-$ terpineol, and 4-terpineol. Two hemiterpene were detected in oil from Buru Island and Papua including 3methylbutanal and 2,4-pentanediol. The oxygenated sesquiterpenes were only detected in oil from Malang including ledol, globulol, epiglobulol, and viridiflorol. The common monoterpene hydrocarbons detected in all samples were $\alpha$-pinene, $\beta$-pinene, $\beta$-myrcene, limonene, $p$-cymen, 3-carane, $\quad \gamma$-terpinene, and terpinolene. However, the common sesquiterpene hydrocarbons detected in all samples were caryophyllene, $\alpha$-gurjunene, $\alpha$-humulene, cadinene, $\alpha$-salinene, valencene, and germacrane B. All cyclic monoterpenes were derived from $\alpha$-terpinyl cation formed by cyclization of LPP. However all cyclic sesquiterpenes were derived from germacrane and humulene.

\section{ACKNOWLEDGMENT}

We thanks the Faculty of Mathematics and Natural Science, Universitas Negeri Malang, Indonesia, for financial support through the PNBP (Penerimaan Negara Bukan Pajak) Research Grant 2018.

\section{REFERENCES}

[1] Craven, L.A. \& Barlow, B.A, New Taxa and New Combinations in Melaleuca (Myrtaceae), Novon, 1997, 7, pp: 113-119.

[2] Doran, J.C., "Cajuput oil". In: Southwell, I.A. \& Lowe, B. (Editors): Medicinal and Aromatic Plants - Industrial Profiles . Tea Tree, the Genus Melaleuca. Amsterdam: Harwood Academic Publishers, 1999, pp:. 225, 227.
[3] Brophy, J.J. \& Doran, J.C., "Essential oils of tropical asteromyrtus, callistemonand melaleuca species": in Search of Interesting Oils with Commercial Potential, ACIAR Monograph No. 40, ACIAR, Canberra, 1997, pp: $62-63$.

[4] Pino, J., Bello, A., Urquiola A., Aguero J., \& Marbot, M., "Chemical composition of cajuput oil (Melaleuca leucadendra L.) from Cuba", J. Essent. Oil. Res, 2002, 14, pp:10 - 11.

[5] Padaliaa, R.C., Vermaa, R.S, Chauhana, A., Chanotiya, C.S., The essential Oil Composition of Melaleuca leucadendra L. Grown in India: A Novel Source of (E)-nerolidol, Industrial Crops and Products, 2015, 69, pp: 224-227.

[6] Kumar, A., Tandon, S., \& Yadav, A., "Chemical composition of the essential oil from fresh leaves of Melaleuca leucadendron $l$. from north India", Journal of Essential Oil Bearing Plants, 2013, Vol. 8, No. 1, pp: 19-22.

[7] Sekasegawa, M., Hori, K., \& Yatagai, M., "Composition and antitermite activities of essential oils from Melaleuca species", J. Wood Sci, 2003, Vol 49, pp: $181-187$.

[8] Motl, O., Hodatova, J., \& Ubik, K., "Composition of Vietnamese cajuput essential oil", Flavour and Fragrance Journal, 1990, Vol. 5, pp: 39-42.

[9] Cuong, N.D. \& Xuyen, T.T., "Antibacterial properties of Vietnamese cajuput oil", Journal Essential Oil Research, 1994, Vol. 6, pp: $63-67$.

[10] Vuuren, S.F. van. \& Viljoen, A.M., "Antimicrobial activity of limonene enantiomers and 1,8-cineole alone and in combination", Flavour and Fragrance Journal, 2007, 22, pp: 540-544.

[11] Tzakou, O., Pitarokili, D., Chinou, I.B., \& Harvala, C., "Composition and Antimicrobial Activity of the Essential Oil of Salvia ringens", Planta Med, 2001, 67, pp: 81-83.

[12] Shunying, Z., Yang, Y., Huaidong, Y., Yue, Y., \& Guolin, Z., "Chemical Composition and Antimicrobial Activity of the Essential Oils of Chrysanthemum indicum", Journal of Ethnopharmacology, 2005, 96, pp: 151-158.

[13] Jiang, Y., Wu, N., Fu, Y-J., Wang, W., Luo, M., Zhao, C-J., Zu, Y-G., \& Liu, X-L., "Chemical composition and antimicrobial activity of the essential oil of rosemary", Enviromental Toxicology and Pharmacology, 2011, 32, pp: 63-68.

[14] Hammer, K.A., Carson, C.F., \& Riley, T.V., "Antifungal effects of Melaleuca alternifolia (tea tree) oil and its components on Candida albicans, Candida glabrata, and Saccharomyces cerevisiae", Journal of Antimicrobial Chemotherapy, 2004, 53, pp: 1081-1085. 
[15] Mourey, A. \& Canillac, N., Anti-Listeria monocytogenes Activity of Essential Oils Components of Conifers, Food Control, 2002, 13, pp: 289-292.

[16] Lang, G. \& Buchnauer, G., "A review on recent research results (2008-2010) on essential oils as antimicrobials and antifungals". A Review, Flavour and Fragrance Journal, 2012, 27, pp: 13-39.

117] Calcabrini, A., Stringaro, A., Toccacieli, L., Meschini, S., Marra, M., Colone, M., Slavatore, G., Mondello, F., Arancia, G., \& Molinari A., "Terpinen-4-ol, the main component of Melaleuca alternifolia (tea tree) oil inhibits the in vitro growth of human melanoma cells", The Journal of Investigative Dermatology, 2004, 122:2, pp: 349-360.

[18] Hammer, K.A., Carson, C.F., \& Riley, T.V., "Antifungal activity of the components of Melaleuca alternifolia (tea tree) oil", Journal of Applied Microbiology, 2003, 95,pp: 853-860.

[19] Kim, H-J., Chen, F., Wu, C., Wang, X., Chung, H.Y., \& Jin, Z., "evaluation of antioxidant activity of Australian tea tree (Melaleuca alternifolia) oil and its components", Journal of Agricultural and Food Chemistry, 52 (2004), 2004, 2849-2854.

[20] Dewick, P. M., Medicinal Natural Product: A Biosynthetic Approach (Second Edition). England: John Wiley \& Sons Ltd, 2002. 